\title{
Institutional Ownership Composition and Earnings Management
}

\author{
Ling Lin \\ University of Massachusetts Dartmouth \\ llin@umassd.edu \\ Pavinee Manowan \\ Chulalongkorn University \\ pavinee@acc.chula.ac.th
}

Contact Information for Ling Lin (Contact Author)

Email: 1lin@umassd.edu

Tel: 1-508-999-8053

Fax: 1-508-999-8646 
Abstract: This paper first examines outside block-holders' impact on earnings management using discretionary accounting accruals as the measure of earnings management. For the income-decreasing earnings management scenario, we do not find significant results. This may be attributable to the different natures and time horizons of outside block-holders. Since the majority of outside block-holders are institutional investors, we then investigate the relationship between ownership by institutional investors with different natures and earnings management. Specifically, we find a significant positive relationship between ownership by transient institutional investors (holding diversified portfolios with high turnover) and discretionary accounting accruals. We also find a negative relationship (not significant) between ownership by dedicated institutional investors (holding concentrated portfolios with low turnover) and discretionary accounting accruals. Therefore, due to the differing natures of outside block-holders (e.g.: institutional investors), we may not treat them as a homogeneous group. 


\section{Introduction}

Outside block-holders, who beneficially own at least 5 percent of a firm's outstanding common stocks but do not serve as executive officers or directors, are an important external mechanism which governs managers. Because of this importance to managers, two competing views have emerged with regard to the association between outside block-holders and earnings management. One view notes that outside block-holders have more incentives to monitor managers because monitoring is more cost-efficient for outside block-holders as compared to the smaller shareholders. This higher incentive of outside block-holders in monitoring managers' actions potentially reduces earnings management by restricting managers' discretion with financial reporting. A second view notes that outside block-holders exert more pressure on managers to report favorable financial performance than do small shareholders. Therefore, the stronger the existence of outside block-holders, the more likely it may be to create extra pressure for those firms' managers to engage in income-increasing earnings management.

To investigate these potential relationships, we obtain data on outside block-holders from Gompers et al. at WRDS. and use discretionary accruals as a proxy for earnings management. The data was cleaned from possible biases and errors observed for this type of data. Block-holders' data is reported by the firm for the period 1996-2001 and contains standardized data for block-holders of 1,913 companies. Within this data set, we do not find significant results when examining the relationship between outside 
block-holders and earnings management in the income-decreasing earnings management scenario. This result urges a re-examination of the different natures of outside block-holders.

Institutional investors represent the majority of outside block-holders. In recent years, there has been an increasing focus on the role of institutional investors in monitoring, disciplining and influencing corporate managers. Some studies find that institutional investors have a degree of effectiveness in forcing managers to focus on economic performance and to refrain from opportunistic self-serving behavior (e.g. Smith, 1996, Del Guercio and Hawkins, 1999). There is, however, some research which finds that institutional investors are fixated on short-term performance -- even to the detriment of the long-term prosperity of the firm (e.g. Demirag, 1998). These conflicting results may be partially due to the different natures of institutional investors under different study settings. Based on past investment behavior, Bushee (1998) classifies institutional investors into three categories: transient institutional investors who hold diversified portfolios with high turnover; dedicated institutional investors who hold concentrated portfolios with low turnover; and quasi-indexers who hold diversified portfolios with low turnover. Bushee (1998) finds that firms with higher transient institutional are more likely to reduce $R \& D$ expenditures to reverse an earning decrease. Bushee (2001) also finds that higher levels of transient ownership are associated with an over- (under-) weighting of near-term (long-term) expected earnings. Hence, this finding supports the concerns that many managers have about the adverse effects of an ownership base dominated by short-term-focused 
(transient) institutional investors. Inspired by Bushee's results, this research examines the relationship between earnings management and different groups of institutional investors. Specifically, we find a significant positive relationship between transient institutional investors (holding diversified portfolios with high turnover) and discretionary accounting accruals. We find a negative relationship between dedicated institutional investors (holding concentrated portfolios with low turnover) and discretionary accounting accruals.

This research differs from prior studies in several aspects. First, the results are in contrast with previous conclusions regarding the effect of institutional ownership on earnings management. Rajgopal, Jiambalvo, and Venkatachalam (2002) and Shang (2003) find that institutional ownership is associated with reduced use of discretionary accruals. However, they do not distinguish between various institutional investment horizons, treating all institutional investors as a homogeneous group. We find the negative correlation between institutional ownership and accruals manipulation is driven entirely by dedicated institutions and quasi-indexers. Ownership by transient institutional investors is actually positively related to the use of accruals manipulation.

Second, prior studies used a balance-sheet-based accrual approach as a proxy for total accruals when examining the impact of institutional investors on earnings management. Chung, Firth and Kim (2002) define total accruals as the change in non-cash current assets minus change in current liabilities minus depreciation and amortization expenses. However, we calculate total accruals directly from the statement of cash flows as suggested by Collins and Hribar (2002), which is now the current 
method in more recent research.

Third, prior studies examine how institutional investors affect the incidence of R\&D deductions (Bushee 1998), meeting or exceeding expectations (Matsumoto 2002), and accounting restatements (Liu 2006). Since they focus on firms which are more likely to take actions to avoid negative earnings news (some special scenarios), their samples are not representative of the spectrum of earnings management. This paper presents a broader view of the impact of institutional investors on earnings management.

The remainder of this article is organized as follows: In section 2 we briefly review the earnings management literature and the role of outside block-holders in monitoring earnings management. We also develop the idea that institutional investors with different natures will have different impacts on earnings management. The sample selection and research design are introduced in Section 3. Section 4 presents empirical results and additional tests. Conclusions are presented in Section 5.

\section{Incentives for engaging in and monitoring earnings management}

\subsection{Mangers' incentives to engage in earnings management}

Schipper (1989) provides the following definition of earnings management: "Earnings management occurs when managers use judgment in financial reporting and in structuring transactions to alter financial reports to either mislead some shareholders about the underlying economic performance of the company or to influence contractual outcomes that depend on reported accounting numbers."

As Schipper notes, earnings management includes accrual-based and real 
earnings management, such as changes in accounting principals and estimates, investments, and financing decisions. There are respective benefits and costs associated with accrual manipulation and real decision manipulation. For accrual manipulation, the benefit is that accruals are not easy to detect and there is flexibility in manipulating accruals. The cost is that accruals will reverse in the following period, perhaps even $100 \%$, and there may not be enough accruals to manipulate. The benefit of real decision manipulation is that it is difficult to identify. The cost is that it has the potential for high future loss to the firm's value.

This paper examines managers' opportunistic behavior of manipulating discretionary accruals, rather than real activities. The incentives for managers to manipulate discretionary accruals could stem from their compensation contract, given that accounting numbers, including earnings, are often used in setting executive compensation. The incentives could also come from the valuation of IPOs, management buyouts and debt covenants. Empirical research has investigated whether there is an evidence of earnings management in the presence of those situations, and, many studies find that corporate managers opportunistically manage reported earnings. (e.g.: Teoh et al., 1997; Rangan, 1998).

\subsection{The role of outside block-holders in monitoring managers}

With regard to the association between outside block-holders and earnings management, there are two competing views. One view is that outside block-holders have more incentives to monitor the actions of managers than do small outside shareholders because monitoring is more cost-efficient for outside block-holders. 
Small outside shareholders can sell their stocks quickly if they are not satisfied with the performance of managers. However, selling a large block of stocks often triggers the stock price to plunge. Outside block-holders generally have to adopt a relatively long-term strategy. Consequently, the monitoring of managers produces more benefits for outside block-holders than for outside small shareholders. The higher incentive of outside block-holders in monitoring managers' actions potentially reduces earnings management by restricting managers' discretion with financial reporting.

A second view proposes that outside block-holders exert more pressure on managers to report favorable financial performance than do small shareholders. Block-holders could pressure managers to take specific actions or call for dismissal of the managers whenever the company appears to be performing below its potential. Therefore, the existence of outside block-holders in this view actually creates extra pressure for those firms' managers to engage in income-increasing earnings management. The two competing views are not mutually exclusive since the question of how outside block-holders affect earnings management depends on which of the two conflicting factors would dominate. This determination is made after reviewing the costs and benefits of the earnings management to outside block-holders.

\subsection{The role of institutional investors in monitoring managers}

Institutional investors represent the majority of outside block-holders. Based on past investment behavior, Bushee (1998) classifies institutional investors into three categories: transient institutional investors, holding diversified portfolios with high 
turnover; dedicated institutional investors, holding concentrated portfolios with low turnover; and quasi-indexers, holding diversified portfolios with low turnover. Transient institutional investors are short-term investors and they trade heavily on earnings news. Ke and Ramalingergowa (2004) find that the quarterly change in transient institutional investors' stock stake is positively correlated with the current quarter's earnings surprise. Transient institutional investors trade heavily on earnings news without significant incentives to monitor firms' management. They are likely to sell the firms stock in the absence of current profits instead of trying to monitor management to adopt value-increasing policies. Graves (1988) argues that fund managers cannot afford to take the long view in their investment decisions since they are reviewed and rewarded on the basis of quarterly or, at most, annual performance measures. Kim, Krinsky, and Lee (1997) report that there is greater stock return volatility and trading volume surrounding earnings announcements with high institutional ownership, supporting institutional transience. Bushee (1998) examines the situation where managers reduce $R \& D$ expenses to reverse an earnings decline. He finds that firms with higher transient institutional ownership are more likely to cut R\&D to maintain short-term earnings growth. Matsumoto (2002) documents that the transient institutional investors' stake is positively related with managers' propensity to avoid negative earnings surprises. Liu and Peng (2006) find that firms with higher transient institutional ownership have lower accruals quality. Hence, we hypothesize the higher the transient institutional ownership, the more likely the income-increasing earnings management. The higher the transient institutional ownership, the less the 
income-deceasing earnings management is used.

In contrast, dedicated institutional investors are long-term investors holding a concentrated portfolio with low turnover and they have greater incentives to collect information, monitor management actions, and urge better performance in the long run. Because of the longer investment horizons of dedicated institutional investors, they want firm managers to focus on long-term profitability rather than be pre-occupied with managing earnings on a year-by-year basis. They would discourage managers from using discretionary accruals to engage in earnings management, especially discouraging managers from engaging in income-increasing earnings management when pressured by the transient institutional investors. (Bushee 1998; Gasper et al. 2005). The monitoring role of dedicated institutional investors suggests that dedicated institutional investors would curb the managers' opportunistic behavior, especially in the income-increasing scenarios created from the intense pressure from transient institutional investors.

\subsection{Managerial share ownership}

Managerial ownership could have an impact on the use of discretionary accruals. Warfield et al. (1995) find (1) a positive relationship between managerial ownership and the information content of earnings and (2) a negative relationship between managerial ownership and the magnitude of absolute discretionary accruals. However, Francis et al. (1999) conclude that there is no systematic relationship between management ownership and accounting accruals. However, because this research focuses on the impact of outside block-holders and institutional investors' ownership 
on earnings management, we elected not to incorporate a management ownership variable in the model. However, we did run a regression to examine the impact of managerial ownership on discretionary accruals and the results are consistent with Francis et al. (1999). (See Appendix A).

\section{Research design}

\subsection{Measure of total accruals and discretionary accruals}

The traditional approach to calculate total accruals is as follows:

Total Accruals

$=[\Delta$ Accounts Receivable $(\# 2)+\Delta$ Inventories $(\# 3)$

$+\Delta$ Other Current Assets (\# 68) $]-[\Delta$ Current Liabilities (\#5) $]$

- [Depreciation \& Amortization Expense (\#14)]

where the change $(\Delta)$ is the difference between years $t$ and $t-1$.

However, this balance-sheet-based approach has been questioned by Collins and Hribar (2000). They measure accruals using the changes in the current accounts disclosed on the SFAS 95 (FASB, 1987) statement of cash flow from operations. Collins and Hribar (2000) document that the approaches taken to estimate accruals as the difference in succeeding balance sheet amounts induces measurement error due to the failure to adjust for merger/acquisition and divestiture activity. They further document that if partitioning variables used to indicate the presence of earnings management is correlated with variables related to merger/acquisition or divestiture activity, the measurement error in discretionary accrual estimates could lead the researcher to conclude that earnings management exists when there is, in fact, none. 
The manner in which Collins and Hribar (2000) measure discretionary accruals has been widely used in recent studies (Xie 2001; Fan and Qintao 2007). Thus, following the current literature, we calculate total accruals directly from the statement of cash flows as suggested by Collins and Hribar (2002):

$\mathrm{TACi},=\mathrm{EBXI}(\# 123)-\mathrm{CFO}(\# 308-\# 124)$

where:

EBXI $=$ earnings before extraordinary items and discontinued operations

$\mathrm{CFO}=$ cash flow from continuing operations.

Using the modified Jones model, we estimate total accruals as a function of changes in sales revenues minus changes in account receivables, property, plant, and equipment. Formally:

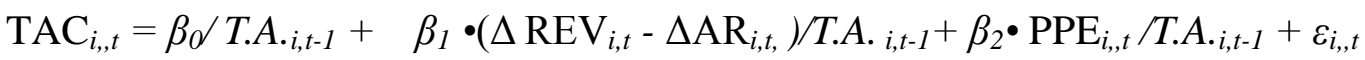

Where, for firm $i$ in year $t: \quad \mathrm{TAC}_{i, t}$ has been defined in Eq. (2)

$T \cdot A_{\cdot, t-1}=$ lagged total assets

$\Delta \mathrm{REV}_{i, t}=$ change in sales revenue

$\Delta \mathrm{AR}_{i, t}=$ change in accounts receivables

$\mathrm{PPE}_{i, t}=$ property, plant and equipment

For each year and industry (based on two-digit SIC codes), we estimate regression parameters in Eq (3) using cross-sectional observations. Nondiscretionary accruals are defined as the fitted value from Eq. (3). Discretionary accruals (DAC) are estimated as the difference between total accruals (TAC) and its fitted value, i.e. the residual from Eq. (3). Consistent with accounting literature, DAC is assumed to be the 
outcome of managers' opportunistic choices of discretionary accruals.

\subsection{Measures of outside block-holders ownership and institutional ownership}

Outside block-holders ownership data is obtained from the database provided by Gompers et al. at WRDS. The data was cleaned from biases and errors observed in sources for this type of data. Block-holders' data is reported by the firm for the period 1996-2001 and contains standardized data for block-holders of 1,913 companies.

For institutional ownership, the data is obtained from CDA spectrum (Thomson Financial), which contains the institutional ownership data from the SEC's form 13(f). At the end of each calendar quarter, any institutional investors with greater than $\$ 100$ million in equity securities must file Form 13(f), which discloses their common stock holdings of greater than 10,000 shares or $\$ 200,000$. We averaged the quarterly holdings of outstanding shares owned by institutional investors to calculate the annual institutional ownership. We then identified transient institutional ownership, dedicated institutional ownership and quasi-indexing institutional ownership according to institutional classification by Bushee $(2001)^{1}$. The classification is performed using factor and cluster analysis on institutional investor' past investment behavior. This classification is done on a year-by-year basis. However, Ke and Ramalingegowda (2005) find that the classification remains mostly unchanged over time.

\subsection{Regression model}

\footnotetext{
${ }^{1}$ We thank Bushee for providing the classification data.
} 
To examine the impact of outside block-holders' impact on earnings management, we investigate two different scenarios. First, the income-increasing earnings management scenario using positive discretionary accounting accruals as the proxy (where DAC >0). Second, the income-decreasing earnings management scenario using negative discretionary accounting accruals as the proxy (DAC $<0)$. The regression model is:

$$
\mathrm{DAC}_{i, t}=\beta_{0}+\beta_{1} \mathrm{OUT}_{+} \beta_{2} \mathrm{SIZE}_{i, t+} \beta_{3} \mathrm{RISK}_{i, t+} \beta_{4} \mathrm{LEV}_{i, t+} \beta_{5} \mathrm{CFO}_{i, t+} \varepsilon_{i, t}
$$

Where, for firm i in year t, DAC = discretionary accruals estimated from Eq.(3); OUT is percentage of shares held by all outside block-holders, obtained from Gompers's block-holder database at WRDS; SIZE is measured as the log of market value of equity (data\#25*data\#199); RISK is market model beta using daily returns calculated for each fiscal year; LEV is the ratio of total debt over total assets (data\#9+data\#34)/data\#6; CFO is cash flow from operations (data\#308).

Since there are two competing views regarding the relationship between outside block-holders and earnings management as mentioned in section 2.2, the effect of outside block-holders on earnings management depends on which of the two conflicting factors dominates; we do not have any prediction for the sign of $\beta 1$.

To examine how the earnings management is affected by institutional investors classified by different investment behavior, we employ the following regression:

$$
\begin{aligned}
\mathrm{DAC}_{i, t}= & \beta_{0}{ }_{+} \beta_{1} \mathrm{TRA}_{i, t+} \beta_{2} \mathrm{DED}_{i, t+} \beta_{3} \mathrm{QIX}_{i, t+} \beta_{4} \mathrm{SIZE}_{i, t} \\
& { }_{+} \beta_{5} \mathrm{RISK}_{i, t+} \beta_{6} \mathrm{LEV}_{i, t+} \beta_{7} \mathrm{ROA}_{i, t}+\beta_{8} \mathrm{CFO}_{i, t+} \varepsilon_{i, t}
\end{aligned}
$$

Where, for firm $\mathrm{i}$ in year $\mathrm{t}$, TRA is shares owned by transient institutional investors divided by shares outstanding; DED is shares owned by dedicated institutional investors divided by shares outstanding; QIX is shares owned by quasi-indexing institutional investors divided by shares outstanding; and the rest of variables are defined in Eq. (4).

Given that transient institutional investors focus on short-term performance and place intense pressure on managers to report favorable financial performance, we 
hypothesize that transient institutional investors' ownership is positively related to the magnitude of discretionary accruals in the income-increasing scenario. i.e. when DAC $>0$, we hypothesize that the sign of $\beta 1$ is positive. The higher the transient institutional ownership, the more likely the presence of income-increasing earnings management. Meanwhile, dedicated institutional investors would play the role to attenuate transient institutional investors' impact, so the predicted sign of $\beta 2$ is negative. From another point of view, due to the long investment horizon of dedicated institutional investors, they want firm managers to focus on long-term profitability rather than be pre-occupied with managing earnings on a year-by-year basis. They would discourage managers from using discretionary accruals to engage in income-increasing earnings management due to the intense pressure from transient institutional investors. In this sense, the predicted sign of $\beta 2$ is also negative.

As for the income-decreasing scenario (DAC $<0$ ), since transient institutional investors are in favor of better financial performance, they want less income-decreasing discretionary accruals, i.e. less negative DAC. Therefore, when $\mathrm{DAC}<0$, we hypothesize that the sign of $\beta 1$ is positive. For the sign of $\beta 2$, there are two competing forces to mitigate transient institutional investors' impact. $\beta 2$ should have the opposite predicted sign of $\beta 1$, so $\beta 2$ is negative. However, the monitoring role of dedicated institutional investors follows that the sign of $\beta 2$ should be positive, i.e. discourage managers from engaging in income-decreasing earnings manipulation. Hence, we do not predict the sign of $\beta 2$ in the income-decreasing scenario when DAC $<0$. Quasi-indexing investors use buy-and-hold strategies and prior literature has 
conflicting predictions about their incentives as monitors, hence, we do not have any prediction for the coefficient on QIX.

\subsection{Sample selection}

As mentioned in section 1, Gomper's block-holders database, which consists of firms' observations during the period 1996-2001, is used for data. We focus on active U.S. firms on Compustat during the years 1996 and 2001. The data screening process is illustrated in Table 1. Beginning with 37,501 firm-year observations for 1996 and 2001, 7,399 firm-year observations were dropped due to missing values of regression variables in a modified Jones model. For specific variables involved in this procedure, please refer to Eq. (3). Since we use a cross-sectional Jones model to estimate non-discretional accruals, we impose a criterion that per year per industry, there must be at least 20 firm-year observations to be included in the estimation sample. The final regression sample consists of 18,969 firm-year observations used to estimate the coefficients in Eq.(3)

$\mathrm{TAC}_{i, t}=\beta_{0} T \cdot A_{\cdot i, t-1}+\beta_{1} \bullet\left(\Delta \mathrm{REV}_{i, t}-\Delta \mathrm{AR}_{i, t}\right) / T \cdot A \cdot i, t-1+\beta_{2} \bullet \mathrm{PPE}_{i, t} / T \cdot A \cdot i, t-1+\varepsilon_{i, t}$

The above coefficients are applied to the block-holders sample to calculate the discretionary accruals for the firm-year observations with required data from both Compustat and Gomper's Block-holders databases. The final sample consists of 3,141 firm-year observations. For those 3,141 firm-year observations, the institutional ownership data on the CDA spectrum, which contains the institutional ownership data from the SEC's Form 13(f) will be used. Table 2 reports descriptive statistics and Pearson Correlation Coefficients for the major research variables. Discretionary 
accounting accruals (DAC) divided by lagged total assets has a mean value (median value) of $-0.6 \%(-0.1 \%)$, indicating that, on average, DAC is income-decreasing. The mean (median) for shareholdings by outside block-holders (OUT) is 16.8\% (14.3\%), therefore, there is considerable stake held by outside block-holders. Notice that transient the institutional investors' stake is twice that of the dedicated institutional investors, as evidenced by the mean values of $24.2 \%$ and $12 \%$ for these two categories respectively. The quasi-indexers also hold considerable ownership, with a mean value of $34.1 \%$ and median value of $32.4 \%$. The shareholdings by institutional investors in the sample are somewhat high, as we focus on the firms' years covered by the Gompers' block-holders database.

Panel B of Table 2 shows Pearson correlation coefficients. DAC is positively correlated with outside block-holders ownership (OUT) with p-value $<0.001$ under the circumstance of income-increasing earnings management $(\mathrm{DAC}>0)$. DAC is negatively correlated with outside block-holders ownership (OUT) with p-value 0.087 when DAC $<0$. Taken together, the outside block-holders encourage managers to engage in earnings management in both scenarios. Since transient institutional investors dominate dedicated institutional investors as evidenced by the mean values, it is not surprising to see the correlation coefficients between DAC and TRA have the same signs as those between DAC and OUT. Meanwhile, the correlation between DED and DAC is insignificant, and QIX and DAC do not have a strong relationship either. We will further examine the relationship between DAC and different categories of institutional investors in a multi-variable regression. 


\section{Empirical Results}

\subsection{Main results}

Table 3 presents results for the regression of DAC on outside block-holders, and other control variables using Eq. (4). Consistent with Pearson correlation coefficients, when DAC $>0$, DAC is positively correlated with OUT, significant at $1 \%$ level controlling for other firm characteristics, it follows that outside block-holders exacerbate managers' upward earnings management. When DAC $<0$, OUT has a negative coefficient, but not significant finding. This result motivates further examination of the relationship between DAC and different categories of institutional investors, not treating them as homogeneous investors.

Table 4 presents results for the regression of DAC on institutional investors, and other control variables using Eq. (5). When DAC >0, ownership by transient institutional investors is significantly positively correlated with the magnitude of discretionary accruals. In other words, transient institutional investors exacerbate managers' upward earnings management. When DAC $<0$, ownership by transient institutional investors is still significantly positively correlated with discretionary accruals, implying that the higher the ownership by transient institutional investors, the less negative discretionary accruals. In both scenarios, DAC $>0$ and DAC $<0$, transient institutional investors always prefer higher income, which is consistent with the hypothesis developed in section 2.3 and the coefficient signs predicted in section 3.3. The results are consistent with the argument that transient institutional investors often invest for short-term horizons, suggesting that they may influence companies to 
use positive accounting accruals. In other words, managers may feel intense pressure from transient institutional investors to improve current profitability and managers may resort to using income-increasing discretionary accruals to satisfy these investors.

As for the association between DAC and DED, the correlation is not significant. In fact, when DAC $>0$, the coefficient on DED is negative, implying (effect is non significant) that dedicated institutional investors try to keep management away from using income-increasing earnings management. When $\mathrm{DAC}<0$, the coefficient on DED is negative. This indicates that dedicated institutional investors are trying to mitigate the impact of transient institutional investors. In both scenarios, the coefficients on DED have the opposite sign when compared to coefficients on TRA. Surprisingly, the coefficients on QIX always have the same sign as those on DED, suggesting that quasi-indexing institutional investors function in a similar way as dedicated institutional investors. In sum, due to the different investment horizons, we may not treat institutional investors as a homogeneous group.

\subsection{Additional tests}

\subsubsection{Granger causality test}

There may be an alternative explanation for the positive (negative) association between transient (dedicated) institutional ownership and discretionary accruals. Transient (dedicated) institutional investors could choose to invest in firms with higher (lower) income-increasing earnings management. To address this issue, we follow Ajinkya et al. (2005) and conduct a Granger causality test. Specifically, we add 
lagged discretionary accruals as an independent variable to Eq. (5). The Granger causality test eliminates the impact of prior earnings management on current institutional ownership, and establishes a causal direction from current institutional ownership to future earnings management.

Table 5 shows regression results with lagged discretionary accruals. The estimated coefficients on TRA remain significantly positive as expected when DAC $>0$. This evidence is consistent with the notion that transient institutional investors exert pressure on managers to engage in income-increasing earnings management after controlling for lagged discretionary accruals. When DAC $<0$, the coefficient on TRA still has a positive sign, although not significant. As for the relationship between dedicated institutional investors and earnings management, there is very weak evidence showing that there is "monitoring effect" of institutional investors. Hence, it is difficult to define the causal direction between dedicated institutional ownership and earnings management.

\subsubsection{Results examined by dummy variables}

Following Chung et al. (2002), dummy variables were created for the institutional share ownership (TRA, DED, QIX) to further examine the results. Specifically, a dummy variable takes on a value of unity if institutional share ownership for the firm is higher than the cross-sectional top quartile in the year. The results are presented in Table 6. As expected, Table 6 mimics the main results presented in Table 4. The coefficients on dummy variables, TRA_D, DED_D, QIX_D, all have the same signs, when compared to those on TRA, DED, and QIX, the actual ownership percentages. 
Meanwhile, the significance remains unchanged, i.e. in both scenarios, DAC $>0$ and DAC $<0$, ownership by transient institutional investors is significantly positively correlated with discretionary accruals, and ownership by dedicated institutional investors are negatively correlated with discretionary accruals in both scenarios, although not significant.

\section{Conclusions}

This paper first examines outside block-holders' impact on earnings management using discretionary accounting accruals as the measure of earnings management. For the income-decreasing earnings management scenario, we do not find significant results. This may be attributable to the different natures and time horizons of outside block-holders. Since the majority of outside block-holders are institutional investors, we then investigate the relationship between ownership by institutional investors with different natures and earnings management. Specifically, we find a significant positive relationship between ownership by transient institutional investors (holding diversified portfolios with high turnover) and discretionary accounting accruals. We also find a negative relationship (not significant) between ownership by dedicated institutional investors (holding concentrated portfolios with low turnover) and discretionary accounting accruals. Therefore, due to the differing natures of outside block-holders (e.g.: institutional investors), we may not treat them as a homogeneous group. 


\section{Reference}

Ajinkya, B., S. Bhojraj, and P. Sengupta. 2005. The Association between Outside Directors, Institutional Investors and the Properties of Management Earnings Forecasts. Journal of Accounting Research 43: 343-376.

Bushee, B.. 1998. The influence of institutional investors on myopic R\&D investment behavior. The Accounting Review 73, 305-333.

Bushee, B. and C. Noe. 2000. Corporate Disclosure Practices, Institutional Investors, and Stock Return Volatility. Journal of Accounting Research 38: 171-202.

Bushee, B.. 2001. Do institutional investors prefer near-term earnings over long-run value? Contemporary Accounting Research 18: 207-46.

Chung, R., M. Firth, and J. Kim. 2002. Institutional Monitoring and Opportunistic Earnings Management. Journal of Corporate Finance 8: 29-48.

Collins, D. W., and P. Hribar. 2002. Errors in estimating accruals: Implications for empirical research. Journal of Accounting Research 40 (March): 105-135.

Dechow, P. M. and Dechev. 2002. The quality of accruals and earnings: The role of accrual estimation errors. The Accounting Review 77 (Supplemental): 35-59

Dechow, P. M., R. G. Sloan, and A. P. Sweeney. 1995. Detecting earnings management. The Accounting Review 70 (April): 193-225.

Del Guercio, D., Hawkins, J., 1999. The motivation and impact of pension fund activism. Journal of Financial Economics 52, 293- 340.

Demirag, I.S., 1998. Corporate Governance, Accountability, and Pressure to Reform: An International Study. JAI Press, Stamford, CT.

Fan, Qintao. 2007 Earnings management and ownership retention for initial public offering firms: theory and evidence. Accounting Review Vol. 82, No.1, pp27-64.

Francis, J.R., Maydew, E.L., Sparks, H.C., 1999. The role of Big 6 auditors in the credible reporting of accruals. Auditing: A Journal of Practice and Theory 18, 17- 34.

Gaspar, J. Massa, M., Matos, P. (2005) Shareholder Investment Horizons and the Market for Corporate Control, Journal of Financial Economics Volume76,issue 1: pp135-165 
Graves, S.B., 1988. Institutional ownership and corporate R\&D in the computer industry. Academy of Management Journal 31, 417-428.

Ke, B., K. Petroni, 2004. How informed are actively trading institutional investors? Evidence from their trading behavior before a break in a string of consecutive earnings increases. Journal of Accounting Research 42: 895-927.

Ke, B., S. Ramalingegowda, 2005. Do institutional investors exploit the post-earnings announcement drift? Journal of Accounting and Economics 39: 25-53.

Liu, Y. 2006. Does Institutional Investor Composition Influence Managerial Myopia? The Case of Accounting Restatements. Working paper, University of Oregon.

Liu, Y and Peng, Y, 2006. Institutional Ownership Composition and Accruals Quality. Working paper, Fordham University.

Mastumoto, D., 2002. Management's Incentives to Avoid Negative Earnings Surprises. The Accounting Review 77: 483-514.

Rajgopal, S., and M. Venkatachalam, 1998. The Role of Institutional Investors in Corporate Governance: An Empirical Investigation. Working paper, University of Washington.

Rajgopal, S., J. Jiambalvo, and M. Venkatachalam, 2002, Institutional ownership and the extent to which stock prices reflect future earnings, Contemporary Accounting Research, $19, \mathrm{p} 117-136$.

Rangan, S., 1998. Earnings management and the performance of seasoned equity offerings. Journal of Financial Economics 50, 101- 122.

Shang, A., 2003. Earnings management and institutional ownership. Unpublished working paper. Harvard University.

Schipper ,K. 1989. Commentary on earnings management. Accounting Horizon3 (December) 91-102.

Smith, M., 1996. Shareholder activism by institutional investors: Evidence from CalPERS. The Journal of Finance 51, 227-252.

Teoh, S. H., I. Welch, and T.J. Wong. 1998. Earnings Management and the Post-Issue Performance of Seasoned Equity Offerings. Journal of Financial Economics 50: 63-99.

Warfield, Terry D.; Wild, John J.; Wild, Kenneth L. 1995 Managerial ownership, accounting choices, and informativeness of earnings. Journal of Accounting \& Economics, Jul95, Vol. 20 Issue 1, p61-91 
Xie,Hong, 2001 The mispricing of abnormal accruals. The Accounting Review Vo.76 No.3 July 2001, pp.357-373. 


\section{Table 1 Regression sample selection}

Sample selection

Active U. S. firms on Compustat in year t between 1996 and 2001

observations

Less:

37,501

(1) Firms with missing regression variables in the modified Jones model

(2) Firms with less than 20 observations per year per industry

(3) Firms with extreme 5\% values in terms of regression variables

Final sample

Note:

a) 18, 969 firm year observations with 4946 firms from year 1996 to year 2001

b) Regression variables in the Modified Jones model refer to:

$T A C_{i, t}=\beta_{0} / T \cdot A \cdot i, t-1+\beta_{1} \bullet\left(\Delta R E V_{i, t}-\Delta A R_{i, t,}\right) / T \cdot A \cdot i, t-1+\beta_{2} \bullet P P E_{i, t} / T \cdot A \cdot i, t-1+\varepsilon_{i, t}$ 
Table 2

\begin{tabular}{|c|c|c|c|c|c|}
\hline \multicolumn{6}{|c|}{ Panel A: Descriptive statistics for major variables } \\
\hline Variable & Mean & Std. Dev. & Median & 25 th Pct1 & 75 th Pct 1 \\
\hline $\mathrm{DAC}$ & -0.006 & 0.067 & -0.001 & -0.034 & 0.030 \\
\hline OUT & 0.168 & 0.145 & 0.143 & 0.059 & 0.249 \\
\hline SIZE & 7.185 & 1. 407 & 7. 147 & 6.250 & 8. 133 \\
\hline RISK & 0.780 & 0.545 & 0.664 & 0.406 & 1. 009 \\
\hline LEV & 0.242 & 0.182 & 0.237 & 0.092 & 0.354 \\
\hline CFO & 0.122 & 0.103 & 0.113 & 0.068 & 0.168 \\
\hline TRA & 0.242 & 0.170 & 0.202 & 0.113 & 0.334 \\
\hline DED & 0.120 & 0.105 & 0.098 & 0.036 & 0.177 \\
\hline QIX & 0.341 & 0.148 & 0.324 & 0.235 & 0.426 \\
\hline \multicolumn{6}{|c|}{ Panel B: Pearson Correlations Coefficients } \\
\hline & OUT & SIZE & RISK & LEV & $\mathrm{CFO}$ \\
\hline $\mathrm{DAC}>0$ & 0.095 & -0.242 & 0.064 & -0.100 & -0.216 \\
\hline \multirow[t]{2}{*}{ p-value } & $<0.001$ & $<0.001$ & $<0.001$ & $<0.001$ & $<0.001$ \\
\hline & TRA & DED & QIX & & \\
\hline $\mathrm{DAC}>0$ & 0.073 & 0.027 & -0.023 & & \\
\hline \multirow[t]{2}{*}{$\mathrm{p}^{-}$-value } & 0.007 & 0.339 & 0.383 & & \\
\hline & OUT & SIZE & RISK & LEV & $\mathrm{CFO}$ \\
\hline $\mathrm{DAC}<0$ & -0.043 & 0.189 & -0.192 & -0.016 & 0.192 \\
\hline \multirow[t]{2}{*}{$\mathrm{p}^{\text {-value }}$} & 0.087 & $<0.001$ & $<0.001$ & 0.1257 & $<0.001$ \\
\hline & TRA & DED & QIX & & \\
\hline $\mathrm{DAC}<0$ & -0.122 & 0.014 & 0.043 & & \\
\hline p-value & $<0.001$ & 0.604 & 0.100 & & \\
\hline
\end{tabular}

Variables are defined as follows:

DAC $=$ Discretionary Accruals $=$ Differences between actual total accruals and the fitted values of the modified Jones model.

OUT $=$ percentage of shares held by all outside block-holders, obtained from Gompers's block-holder database at WRDS.

SIZE $=$ the $\log$ of market value of equity (data\#25*data\#199).

RISK = market model beta using daily returns calculated for each fiscal year.

$\mathrm{LEV}=$ the ratio of total debt over total assets (data\#9+data\#34)/data\#6

$\mathrm{CFO}=$ cash flow from operations (data\#308).

TRA $=$ shares owned by transient institutional investors divided by shares outstanding.

$\mathrm{DED}=$ shares owned by dedicated institutional investors divided by shares outstanding.

QIX = shares owned by quasi-indexing institutional investors divided by shares outstanding. 
Table 3

Regression of discretionary accruals on outside block-holder ownership and other control variables

\begin{tabular}{ccc}
\hline & \multicolumn{2}{c}{ Dependent Variables } \\
\hline Independent & DAC $>0$ & DAC $<0$ \\
Variables & & \\
\hline OUT & 0.02 & -0.011 \\
& $(3.13) * *$ & $(1.16)$ \\
SIZE & -0.001 & 0.006 \\
& $(1.72)$ & $(5.87) * *$ \\
RISK & 0.012 & -0.040 \\
& $(5.91) * *$ & $(15.59) * *$ \\
LEV & -0.022 & -0.027 \\
& $(4.03) * *$ & $(3.42) * *$ \\
CF0 & -0.093 & -0.068 \\
& $(8.67) * *$ & $(4.69) * *$ \\
Intercept & 0.052 & -0.045 \\
& $(10.21) * *$ & $(5.72) * *$ \\
$\mathrm{~N}$ & 1505 & 1558 \\
R-squared & 0.1 & 0.15 \\
\hline significant at $5 \% ; *$ significant at $1 \%$ & \\
\hline
\end{tabular}

Absolute value of $t$ statistics in parentheses

Variables are defined as follows:

DAC $=$ Discretionary Accruals $=$ Differences between actual total accruals and the fitted values of the modified Jones model.

OUT $=$ percentage of shares held by all outside block-holders, obtained from Gompers's block-holder database at WRDS.

SIZE $=$ the $\log$ of market value of equity (data\#25*data\#199).

RISK = market model beta using daily returns calculated for each fiscal year.

LEV is the ratio of total debt over total assets (data\#9+data\#34)/data\#6

CFO is cash flow from operations (data\#308). 
Table 4

Regression of discretionary accruals on institutional investors and other control variables

\begin{tabular}{ccc}
\hline & \multicolumn{2}{c}{ Dependent Variables } \\
\hline Independent & DAC $>0$ & DAC<0 \\
Variables & & 0.013 \\
TRA & 0.021 & $(2.13) *$ \\
DED & $(4.15)^{* *}$ & -0.010 \\
& -0.005 & $(1.09)$ \\
QIX & $(0.59)$ & -0.012 \\
& -0.00656 & $(1.65)$ \\
SIZE & $(1.13)$ & -0.001 \\
& -0.002 & $(1.17)$ \\
RISK & $(3.06)^{* *}$ & -0.010 \\
& 0.008 & $(5.28) * *$ \\
LEV & $(3.94)^{* *}$ & -0.024 \\
& -0.041 & $(4.37) * *$ \\
ROA & $(8.04)^{* *}$ & 0.621 \\
& 0.445 & $(40.71) * *$ \\
CFO & $(23.63)^{* *}$ & -0.514 \\
Intercept & -0.377 & $(33.50) * *$ \\
& $(24.02)^{* *}$ & 0.009 \\
& 0.054 & -1.59 \\
& $(11.68)^{* *}$ & 1314 \\
& 1261 & 0.63 \\
\hline & 0.37 &
\end{tabular}

* significant at $5 \%$;** significant at $1 \%$

Absolute value of $t$ statistics in parentheses

Variables are defined as follows:

DAC $=$ Discretionary Accruals $=$ Differences between actual total accruals and the fitted values of the modified Jones model.

TRA $=$ shares owned by transient institutional investors divided by shares outstanding.

$\mathrm{DED}=$ shares owned by dedicated institutional investors divided by shares outstanding.

QIX = shares owned by quasi-indexing investors divided by shares outstanding.

SIZE $=$ the $\log$ of market value of equity (data\#25*data\#199).

RISK = market model beta using daily returns calculated for each fiscal year.

LEV is the ratio of total debt over total assets (data\#9+data\#34)/data\#6

ROA is the ratio of net income plus interest expense over average total assets

(data\#172+data\#15)/average data\#6

CFO is cash flow from operations (data\#308). 
Table 5

Regression of discretionary accruals on lagged discretionary accruals, institutional investors and other control variables

\begin{tabular}{|c|c|c|}
\hline \multirow[b]{2}{*}{$\begin{array}{c}\text { Independent } \\
\text { Variables }\end{array}$} & \multicolumn{2}{|c|}{ Dependent Variables } \\
\hline & $\mathrm{DAC}>0$ & $\mathrm{DAC}<0$ \\
\hline Lag_DAC & $\begin{array}{c}0.069 \\
(3.97) * *\end{array}$ & $\begin{array}{c}0.034 \\
(2.09) *\end{array}$ \\
\hline TRA & $\begin{array}{c}0.018 \\
(2.99) * *\end{array}$ & $\begin{array}{l}0.010 \\
(1.60)\end{array}$ \\
\hline DED & $\begin{array}{l}0.001 \\
(0.11)\end{array}$ & $\begin{array}{c}-0.013 \\
(1.20)\end{array}$ \\
\hline QIX & $\begin{array}{l}0.001 \\
(0.07)\end{array}$ & $\begin{array}{c}-0.008 \\
(0.99)\end{array}$ \\
\hline SIZE & $\begin{array}{c}-0.00188 \\
(2.31) *\end{array}$ & $\begin{array}{c}-0.001 \\
(0.57)\end{array}$ \\
\hline RISK & $\begin{array}{c}0.008 \\
(3.44) * *\end{array}$ & $\begin{array}{c}-0.006 \\
(2.70) * *\end{array}$ \\
\hline LEV & $\begin{array}{l}-0.037 \\
(5.98) * *\end{array}$ & $\begin{array}{c}-0.018 \\
(2.92) * *\end{array}$ \\
\hline $\mathrm{R} 0 \mathrm{~A}$ & $\begin{array}{c}0.408 \\
(17.61) * *\end{array}$ & $\begin{array}{c}0.604 \\
(34.06) * *\end{array}$ \\
\hline $\mathrm{CFO}$ & $\begin{array}{l}-0.348 \\
(18.07) *\end{array}$ & $\begin{array}{c}-0.520 \\
(28.48) * *\end{array}$ \\
\hline Intercept & $\begin{array}{c}0.049 \\
(9.00) * *\end{array}$ & $\begin{array}{l}0.006 \\
(0.89)\end{array}$ \\
\hline $\mathrm{N}$ & 917 & 954 \\
\hline $\mathrm{R}$-squared & 0.31 & 0.63 \\
\hline
\end{tabular}

* significant at $5 \% ; * *$ significant at $1 \%$

Absolute value of $t$ statistics in parentheses

Variables are defined as follows:

DAC $=$ Discretionary Accruals $=$ Differences between actual total accruals and the fitted values of the modified Jones model.

Lag_DAC $=$ Lagged discretionary accruals

TRA $=$ shares owned by transient institutional investors divided by shares outstanding.

$\mathrm{DED}=$ shares owned by dedicated institutional investors divided by shares outstanding.

QIX = shares owned by quasi-indexing investors divided by shares outstanding.

SIZE $=$ the $\log$ of market value of equity (data\#25*data\#199).

RISK = market model beta using daily returns calculated for each fiscal year.

LEV is the ratio of total debt over total assets (data\#9+data\#34)/data\#6

ROA is the ratio of net income plus interest expense over average total assets

(data\#172+data\#15)/average data\#6

CFO is cash flow from operations (data\#308). 
Table 6

$\begin{gathered}\text { Regression of discretionary accruals on institutional investors } \\ \text { (dummies) and other control variables }\end{gathered}$
Dependent Variables

\begin{tabular}{ccc}
\hline Independent & & \\
Variables & DAC $>0$ & DAC $<0$ \\
\hline TRA_D & 0.008 & 0.004 \\
DED_D & $(3.91) * *$ & $(2.08) *$ \\
& -0.001 & -0.001 \\
QIX_D & $(0.69)$ & $(0.31)$ \\
& -0.001 & -0.004 \\
SIZE & $(0.53)$ & $(2.10) *$ \\
& -0.002 & -0.001 \\
RISK & $(3.25)^{* *}$ & $(1.75)$ \\
& 0.009 & -0.009 \\
LEV & $(4.83) * *$ & $(4.81) * *$ \\
& -0.042 & -0.026 \\
ROA & $(8.66) * *$ & $(4.92) * *$ \\
& 0.429 & 0.624 \\
CFO & $(24.39) * *$ & $(44.26) * *$ \\
& -0.373 & -0.521 \\
Intercept & $(25.08) * *$ & $(36.72) * *$ \\
& 0.055 & 0.01 \\
N & $(12.87) * *$ & $(1.92)$ \\
R-squared & 1261 & 1314 \\
& 0.36 & 0.64 \\
\hline
\end{tabular}

* significant at 5\%; ** significant at $1 \%$

Absolute value of $\mathrm{t}$ statistics in parentheses

Variables are defined as follows:

DAC $=$ Discretionary Accruals $=$ Differences between actual total accruals and the fitted values of the modified Jones model.

TRA_D = dummy variable equal to one if transient institutional ownership is higher than the top quartile in a year

DED_D = dummy variable equal to one if dedicated institutional ownership is higher than the top quartile in a year

QIX_D = dummy variable equal to one if quasi-indexing institutional ownership is higher than the top quartile in a year

SIZE $=$ the $\log$ of market value of equity (data\#25*data\#199).

RISK = market model beta using daily returns calculated for each fiscal year.

LEV is the ratio of total debt over total assets (data\#9+data\#34)/data\#6

ROA is the ratio of net income plus interest expense over average total assets

(data\#172+data\#15)/average data\#6

CFO is cash flow from operations (data\#308). 
Appendix A: Regression of discretionary accruals on managerial
ownership and other control variables

\begin{tabular}{lcc}
\hline & \multicolumn{2}{c}{ Dependent Variables } \\
\hline Independent & DAC $>0$ & DAC $<0$ \\
Variables & & \\
\hline OFF & -0.005 & -0.005 \\
& $(0.4)$ & $(0.37)$ \\
SIZE & -0.002 & -0.001 \\
& $(3.93)^{* *}$ & $(1.57)$ \\
RISK & 0.011 & -0.009 \\
& $(6.28)^{* *}$ & $(4.75)^{* *}$ \\
LEV & -0.040 & -0.027 \\
& $(8.40)^{* *}$ & $(5.20)^{* *}$ \\
ROA & 0.429 & 0.616 \\
& $(24.66)^{* *}$ & $(46.11)^{* *}$ \\
CFO & -0.371 & -0.517 \\
& $(25.64)^{*}$ & $(38.19)^{* *}$ \\
Intercept & 0.057 & 0.009 \\
& $(13.40)^{* *}$ & $(1.65)$ \\
$\mathrm{N}$ & 1505 & 1558 \\
R-squared & 0.35 & 0.64 \\
\hline$*$
\end{tabular}

$*$ significant at $5 \%$;** significant at $1 \%$

Absolute value of $\mathrm{t}$ statistics in parentheses

Variables are defined as follows:

$\mathrm{DAC}=$ Discretionary Accruals $=$ Differences between actual total accruals and the fitted values of the modified Jones model.

$\mathrm{OFF}=$ percentage of shares held by all officer block-holders, obtained from Gompers's block-holder database at WRDS.

SIZE $=$ the $\log$ of market value of equity (data\#25*data\#199).

RISK = market model beta using daily returns calculated for each fiscal year.

LEV is the ratio of total debt over total assets (data\#9+data\#34)/data\#6

$\mathrm{ROA}$ is the ratio of net income plus interest expense over average total assets

(data\#172+data\#15)/average data\#6

CFO is cash flow from operations (data\#308). 